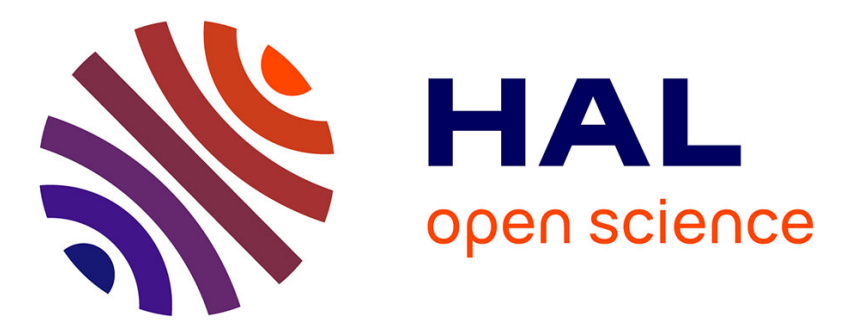

\title{
Near-equivalence of the role of structural unpinning number, basicity and reciprocal average electronegativity in determining the conductivity of glasses
}

\author{
M. C. R. Shastry, K. J. Rao, Alain Levasseur, Ménétrier Menetrier
}

\section{- To cite this version:}

M. C. R. Shastry, K. J. Rao, Alain Levasseur, Ménétrier Menetrier. Near-equivalence of the role of structural unpinning number, basicity and reciprocal average electronegativity in determining the conductivity of glasses. Journal de Physique IV Proceedings, 1992, 02 (C2), pp.C2-171-C2-174. 10.1051/jp4:1992223 . jpa-00251294

\section{HAL Id: jpa-00251294 \\ https://hal.science/jpa-00251294}

Submitted on 1 Jan 1992

HAL is a multi-disciplinary open access archive for the deposit and dissemination of scientific research documents, whether they are published or not. The documents may come from teaching and research institutions in France or abroad, or from public or private research centers.
L'archive ouverte pluridisciplinaire HAL, est destinée au dépôt et à la diffusion de documents scientifiques de niveau recherche, publiés ou non, émanant des établissements d'enseignement et de recherche français ou étrangers, des laboratoires publics ou privés. 


\title{
Near-equivalence of the role of structural unpinning number, basicity and reciprocal average electronegativity in determining the conductivity of glasses
}

\author{
M. C. R. SHASTRY, K. J. RAO ${ }^{(1)}$, A LEVASSEUR and M. MENETRIER
}

Laboratoire de Chimie du Solide du CNRS and Ecole Nationale Supérieure de Chimie et Physique de Bordeaux, 351 Cours de la Libération, 33405 Talence Cedex, France

\begin{abstract}
The chemical approach made to investigate the origin of fast ion conduction in Agl-based fast ion conducting (FIC) glasses has been extended to various ionically conducting systems containing $\mathrm{Na}^{+}$ion. An index known as structural unpinning number (SUN), $S$, has been defined for this purpose based on the unscreened nuclear charge on the cation and the average electronegativity of all the anions. Variation of the log(conductivity), at a given temperature, as a function of structural unpinning number, optical basicity, $\lambda$, and the reciprocal average electronegativity of all the anions, $1 / X_{\mathrm{a}}$, has been examined for a number of $\mathrm{Na}^{+}$-ion conducting glasses and a nearly identical variation has been noticed in all the cases. The equivalence of these chemical parameters as determinants of the conductivity behavior of glasses has thus been established and the origin of this equivalence has been discussed.
\end{abstract}

\section{INTRODUCTION}

Fast ion conducting glasses generally consist of anions of low electronegativity and cations of high unscreened nuclear charge [1]. This causes a redistribution of electronic charges resulting from a reverse charge transfer from anions to cations due to anion-cation interaction [2]. The actual charge on the conducting cation can, therefore, be expected to be lower than its formal charge. The reduction of the electrical charge on cation results in the decrease in the depth of the potential well which becomes relatively shallow [3]. These features together make it appear that cations are 'pulled-up' from otherwise deep potential wells. This is the essence of structural unpinning model.

(1) Permanent address: Solid State and Structural Chemistry Unit, Indian Institute of Science, Bangalore 560012 , India 
Structural unpinning is quantified using a dimensionless 'structural unpinning number;, $\mathrm{S}$, which is given by

$$
\mathrm{S}=\mathrm{C}\left[\mathrm{Z}^{*} / x_{\mathrm{a}}\right]\left[\mathrm{V}_{\mathrm{m}} / \mathrm{N}\right]
$$

Where, $Z^{*}$ is the effective nuclear charge on the cation (calculated using Slater's rules [4]), $X_{\mathrm{a}}$ is the average electronegativity of all the anions (obtained employing Sanderson's method [5]), $V_{m} / N$ is the effective volume available for the cation for its motion in a mole of the glass and $C$ is a constant which renders $S$ non-dimensional.

A plot of isothermal logo vs $S$ for a variety of glasses has been found [1] to give rise to a smooth variation which could be described using a simple relation

$$
\ln \sigma=\ln \sigma_{\mid} /\left(1-e^{-a S}\right)
$$

Where, $\sigma_{1}$ is the limiting isothermal conductivity at high values of $S$ and ' $a$ ' is a numerical constant dependent on the cation.

Hunter and Ingram [6] have recognised a rather similar variation when logo is plotted as a function of (calculated) optical basicity, $\mathcal{\lambda}$. This observation suggests a possible relation between $S$ and $\mathcal{\lambda}$.

\section{DISCUSSION}

In order to investigate the underlying relation between $S$ and $\mathcal{\lambda}$, we have calculated $S$, using equation (1), for borate, silicate and aluminoborate glasses of sodium for which the variation of logo has been studied as a function of $\lambda$ [6]. Plots of log $\sigma$ vs $\lambda$ and $\log \sigma$ vs $S$ are shown in figs. 1 and 2 , respectively. The similarity is rather striking.

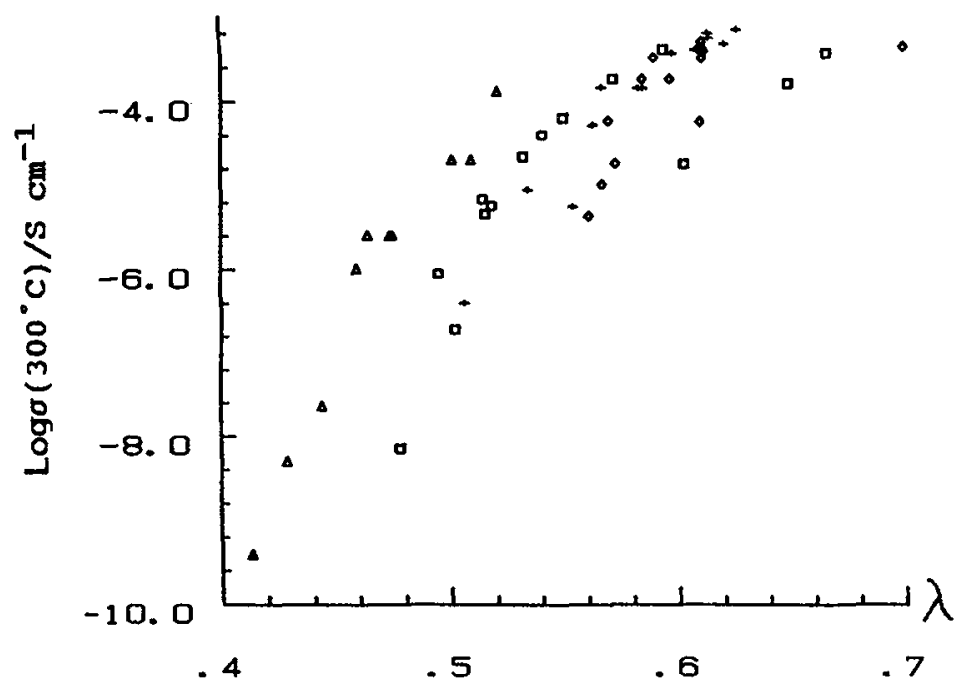

Fig. 1. Variation of the conductivity (at $300^{\circ} \mathrm{C}$ ) with the calculated optical basicity, $\lambda$.

$t=\mathrm{Na}_{2} \mathrm{O}-\mathrm{SiO}_{2} \quad \Delta=\mathrm{Na}_{2} \mathrm{O}-\mathrm{B}_{2} \mathrm{O}_{3} \quad \mathrm{O}=\mathrm{Na}_{2} \mathrm{O}-\mathrm{B}_{2} \mathrm{O}_{3}-\mathrm{SiO}_{2}$

$\square=\mathrm{Na}_{2} \mathrm{O}-\mathrm{Al}_{2} \mathrm{O}_{3}-\mathrm{B}_{2} \mathrm{O}_{3} \mathrm{O}=\mathrm{Na}_{2} \mathrm{O}-\mathrm{Al}_{2} \mathrm{O}_{3}-\mathrm{SiO}_{2}$ 


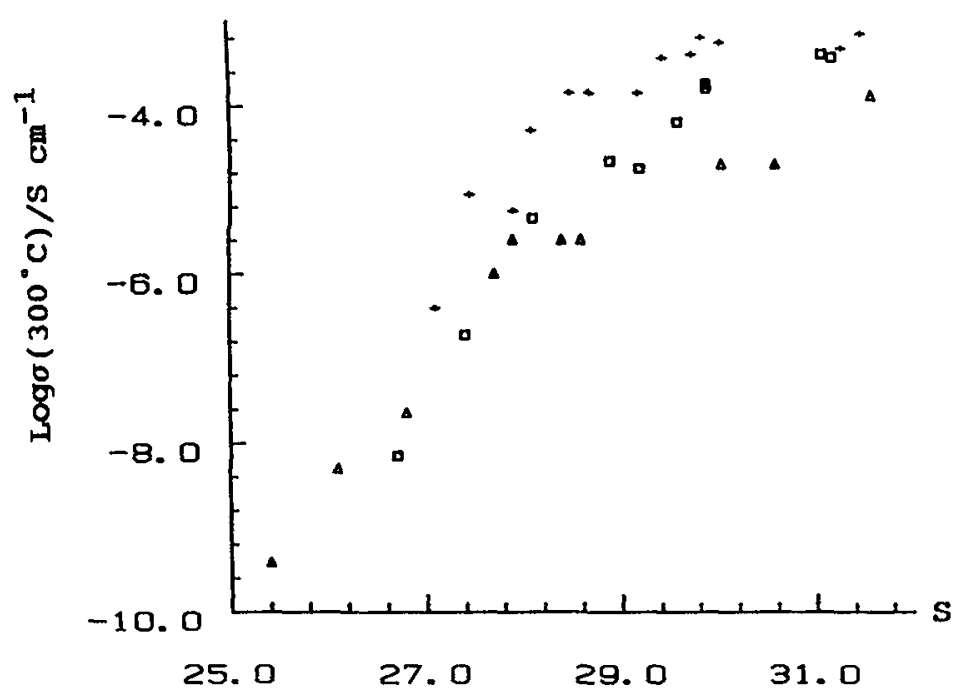

Fig. 2. Variation of the conductivity (at $300^{\circ} \mathrm{C}$ ) with the structural unpinning number, $S$ (symbols, as given in fig. 1 ).

The optical basicities used by Hunter and Ingram have been based on the redshifts observed in the UV absorption edges of probe cations $\mathrm{TI}^{+}, \mathrm{Pb}^{2+}$ or $\mathrm{Bi}^{3+}[7,8]$. Hence the basicities essentially represent the effect of anion matrices on the probe cations in terms of their electron (or oxide ion) donating abilities. Since electron donating ability is inversely related to electronegativity $(\mathcal{X}), 1 / \mathcal{X}$ is also a measure of the basicity. For the same cation, therefore, plot of logo vs $\lambda$ is equivalent to a plot of logo vs $1 / \chi_{a}$. Fig. 3 gives logo vs $1 / x_{a}$ for comparison. The variation in figs. 1,2 and 3 is strikingly similar.

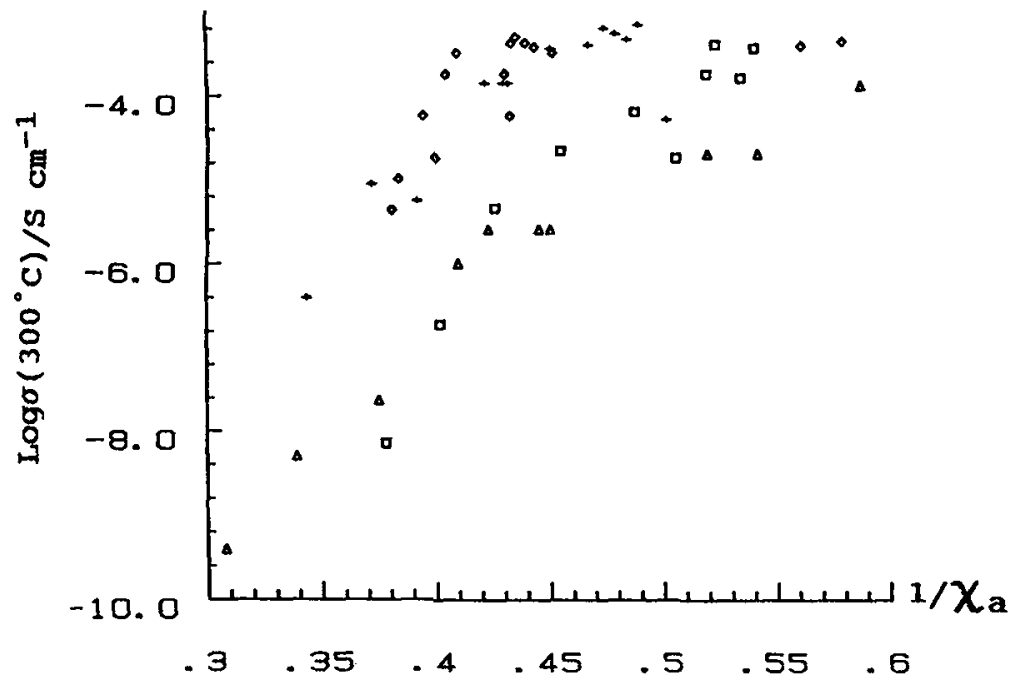

Fig. 3. Variation of the conductivity (at $300^{\circ} \mathrm{C}$ ) with the reciprocal average electronegativity of all the anions, $1 / \chi_{a}$ (symbols, as given in fig. 1). 
Evidently, the relation between basicity and structural unpinning number is uniquely determined through the average electronegativity of the anions for any given cation like $\mathrm{Na}^{+}, \mathrm{Ag}^{+}$or $\mathrm{Li}^{+}$. Hence the plots of log $\sigma$ vs $1 / \chi_{\mathrm{a}}$ or $\mathrm{S}$ would be equivalent, since the variation of $V_{m} / N$ is itself small by comparison. By choosing a suitable scale the nearequivalence of these plots can be demonstrated [9].

\section{CONCLUSIONS}

The near-equivalence of $\mathrm{S}, \mathcal{\lambda}$ and $1 / \chi_{\mathrm{a}}$ in determining the conductivity of the glass, has been demonstrated employing a variety of $\mathrm{Na}^{+}$-ion conducting glasses. The complete equivalence of $S$ and optical basicity for glasses with the same conducting cation is, however, dependent on similarity in $V_{m} / N$ values for a series of such glasses. The usefulness of such universal plots would be enhanced if the basicity of the glasses could be estimated reliably without requiring optical data, such as by the use of $1 / \chi_{a}$.

\section{REFERENCES}

1. M.C.R. Shastry and K.J. Rao Solid State lonics 37 (1989) 17.

2. M.C.R. Shastry and K.J. Rao Pramana (J. Phys.) 32 (1989) 811.

3. M.C.R. Shastry and K.J. Rao Solid State lonics 44 (1991) 187.

4. J.E. Huheey, Inorganic Chemistry: Principles of Structure and Reactivity, $2^{\text {nd }}$ edition (Harper and Row, New York) (1978) p 34.

5. R.T. Sanderson, Ploar Covalence (Academic Press, New York) (1983) p 37.

6. C.C. Hunter and M.D. Ingram Solid State lonics 14 (1984) 31.

7. J.A. Duffy and M.D. Ingram J. Non-Cryst. Solids 21 (1976) 373.

8. J.A. Duffy and M.D. Ingram J. Am. Chem. Soc. 93 (1971) 6448.

9. M.C.R. Shastry, K.J. Rao, A. Levasseur and M. Menetrier Solid State lonics (submitted). 